\title{
Strategic Alternatives for Transforming Public Egyptian Universities to World-Class Universities
}

\author{
Hanaa Ouda Khadri Ahmed \\ Faculty of Education, Ain Shams University
}

doi: 10.19044/esj.2016.v12n10p249 URL:http://dx.doi.org/10.19044/esj.2016.v12n10p249

\section{Abstract}

In the past decade, the term "world-class university (WCU)" - also called "globally competitive universities", “world-class", “elite”, or "flagship" universities- has become a catch phrase. This is simply not only for improving the quality of learning and research in higher education, but is also more significant for developing the competency to compete in the global higher education marketplace through the acquisition and formation of advanced knowledge. The main objective of this paper is to propose strategic alternatives for transforming public Egyptian universities to world-class universities. In achieving this objective, the paper starts by attempting to construct an operational definition of a world-class university. Then, it outlines the features of world-class university, the requirements for transformation into world-class universities, the challenges involved in achieving world-class universities, and the key problems and challenges of the Egyptian higher education system. Finally, the selected statistical population of the research include higher education experts [ $\mathrm{N}=57]$. Thus, a mix method of using a questionnaire and conducting interviews were used. The research questions are: 1- What does it mean for a university to be a world-class university? 2-What are the essential features and characteristics of a world-class university? 3-How does the ecosystem influence the performance of universities? 4-What are the present performance, problems, and challenges of the Egyptian higher education system? 5-What are the higher education reform initiatives in Egypt? 6-What are the requirements that could upgrade public Egyptian universities to world-class universities? 7- What are the existing challenges of developing world-class universities? 8-What strategic alternatives have been developed for transforming public Egyptian universities to world-class universities? Therefore, one-Sample Kolmogorov-Smirnov Test was used to analyze the data. In addition, the result obtained in the study shows the use of collaborative strategic alternative rather than to upgrade the present Public universities, or create or merge them together. 
Keywords: World-class universities, global university rankings, higher education, Egypt

\section{Introduction}

The goal of establishing and changing the university to world-class university is to be able to compete in the global knowledge economy. Furthermore, it also aims in training creative human resources and in advancing national development. In addition, international competitiveness has given intensification to the idea of world-class university. The new concern on 'excellence' in the context of competing universities has been considered as one of the four updated evolutions in higher education (Bellon, 2005, p. 56). The latest survey of higher education trends by The Economist debates stated that "the development of a super-league of global universities," also known as world-class university, is the most momentous development in higher education. As the universal dynamics of higher education enlarged and escalated in complexity, stakeholders in the sector are re-evaluating their priorities and anticipations (World Bank, 2009b: ix). The dynamics have also led to the emergence of the phenomenon that scholars are regarding the World-class universities as Flagship University. Thus, this is a World Class Higher Education Institution that transcends culture and education. They are "points of dignity and comparison among nations that view their own status against other nations" (World Bank, 2009b: $x$ ).

Since the appearance of global university rankings in 2003, the interconnected linking between World-Class Universities and university rankings has been a vibrant topic around the world. Subsequently, not many studies and researches have explored the subject of world-class universities. Therefore, as far as the search is concerned, the researcher has not found similar research on the establishment of world-class universities in Egypt.

As stated by Lin (2009), every country should essentially have a world-class university to perform its role in the world. Lin (2009, p.x) states that:

"No longer are countries comfortable with developing their higher education systems to serve their local or national communities. Instead, global comparison indicators have gained significance in local development of universities”.

To have a world-class university is one of the greatest of all wishes, and it necessitates national, cooperative, and programmed efforts (Altbach, 2007). Furthermore, the same author adds up: "the problem is that no one knows what a world-class university is..."' It may possibly be correct that there is no agreement on a decisive and conclusive concept of "world-class 
university'. However, the research university model is on everyone's mind when the idea of "world-class universities", was brought. Based on this thinking, Egypt should focus on how to transform a few selected universities into world-class universities. An important definition of WCUs was stated by Williams \& Van Dyke (2007).

In the past decade, the term 'world-class university' has turned out to be a catch phrase for not simply advancing the quality of learning and research in higher education. More significantly, it is attained by advancing the competency to compete in the global higher education marketplace through the attainment and formation of progressive knowledge. Since students are searching for admission in the best available institution they can afford, often irrespective of national borders, and since governments has a keen focus on taking advantage of the yields on their investments in universities, universal standing is becoming a progressively important concern for institutions all around the world. Governments have responded to this global reputational competition with extra funding to promote their national elite universities. Thus, this was demonstrated by a range of excellence initiatives in countries such as Denmark, China, Germany, South Korea, Spain, Nigeria, Russia, and Taiwan. In some cases, the government has also encouraged top universities to merge so as to achieve economies of scale. Subsequently, it would also aid the university in attaining an improved position to compete internationally. A few countries have even made decisions to set-up new universities from scratch. However, this is with the sole purpose of creating world-class institutions.

Another definition of a WCU was described by Levin et al. (2006):

"In general, there is wide agreement that great universities have three major roles: (1) Excellence in education of their students; (2) research, development, and dissemination of knowledge; and (3) activities contributing to the cultural, scientific, and civic life of society. Excellence in education means the resources and organization of undergraduate, graduate, and professional instruction and educational opportunities for students. Clearly, this goal requires outstanding faculty, high quality teaching and other instructional activities, and availability of good libraries, laboratories, and other pertinent facilities as well as highly prepared and motivated students who serve to educate through their peer influence. Research, development, and dissemination of knowledge refer to the embryonic identification, growth, and extension of concepts and ideas as well as their transformation into applications, goods, and services that enhance understanding and welfare. Activities 
contributing to the cultural, scientific, and civic life of society are many and varied, but include conferences, publications, artistic events and forums as well as provision of services (e.g. medical clinics and hospitals or museums) that engage and contribute to the larger community including the regional, national, and international communities.”

\section{Statement of the Problem}

World-Class Universities - what they are, how to construct one, how to maintain them (if a country has any), and what are the ways they can authentically contribute to national development efforts (Altbach, 2004; Clark, 1998). The literature does not offer specific answers to the abovementioned questions, but it proposes some features or qualities that have been noticed about WCU (Clark, 2004a; Salmi, 2009). Altbach (2004) proclaims that despite the indefinable description of WCU ("what is it?") or the ways of building world-class universities ("how does a country get it?"), there is a compunction for every nation to have, at least, one WCU.

In the light of what has been mentioned, this study seeks to plan in transforming public Egyptian universities to world-class universities. However, to achieve this objective, the study will answer the study questions.

The main research question in this study is on how to transform public

Egyptian universities to world-class universities. Therefore, this question is broken down as follows:

1. What does it mean for a university to be a world-class university?

2. What are the essential features and characteristics of a world-class university?

3. How does the ecosystem influence the performance of universities?

4. What are the present problems and challenges of the Egyptian higher education system?

5. What are the higher education reform initiatives in Egypt?

6. What are the requirements that could upgrade public Egyptian universities to world-class universities?

7. What are the key existing challenges of developing world-class universities?

8. What strategic alternatives are developed for transforming public Egyptian universities to world-class universities?

\section{Scope and Objectives of the Study}

The main objectives of this study are:

1. Define the concept of a world-class university. 
2. Provide a characterization of a world-class university.

3. Identify the key factors affecting the performance of universities.

4. Discuss the present problems and challenges of the Egyptian higher education system and how these problems and challenges have been solved. 5. Identify the requirements and challenges of transferring public Egyptian universities to world-class universities.

6. Propose possible strategic alternatives for transforming public Egyptian universities to world-class universities.

\section{Significance of the Study}

1. The results of this study will make known what should be done in transforming public Egyptian universities to world-class universities, since having a world-class university is the dream and desire of every nation.

2. The practitioners may benefit from this study by virtue of understanding some of the attendant issues in developing world-class universities in a developing nation setting - its origins, what it entails, what benefits are anticipated, and at what cost.

3. The findings of this study can serve as a map and guide for designing and planning the university system according to international standards.

\section{Research Methodology}

\section{Tools and Methods of Data Collection}

Researcher based on the previous studies used mix method of qualitative method. This is done by means of semi-organized interview and quantitative method through questionnaire. In order to achieve the research objectives, a questionnaire consisting of closed and open questions were used. This questionnaire includes three main parts. The first part assesses the necessity and proportionality of public Egyptian universities with the worldclass university. The second part assesses the existed challenges and problems in two steps. Finally, the third part assesses possible strategic alternatives for transforming public Egyptian universities to world-class universities. Furthermore, the answers to the questions were ranked on a Likert rating scale.

\section{Validity and Reliability of the Questionnaire}

One of the tools used in this research is a questionnaire. Thus, it should be noted that the obvious content validity of the questionnaire were provided through studying the researches and literature of world-class university and world class areas. After the preparation of the questionnaire, it was delivered to a number of faculties and experts of higher education. In addition, their corrective comments and suggestions were taken into consideration. Reliability shows the correctness and accuracy rate of 
collected data for stability and repeatability. Therefore, the test reliability according to Cronbach's Alpha test was $87 \%$.

\section{Statistical Sample and Sampling Method}

Researcher partake of the faculty and experts' views in the field of higher education, educational administration, strategic management, and information technology professionals [statistical population $\mathrm{N}=57$ ]. Thus, this was done randomly in the best university in Egypt which includes: Cairo University, American University in Cairo, Mansoura University, Alexandria University, Benha University, Zagazig University, Assiut University, Minia University, and University of Tanta.

\section{Method of Performing Research and Data Analysis}

After the researcher have proposed the possible strategic alternatives for transforming public Egyptian universities to world-class universities based on literature review, a questionnaire and semi-organized interview was prepared and distributed among 57 faculty and experts. In total, all of them were interested and they agreed to universities' transformation. However, this act is considered to be very difficult, but helps in the promotion of the universities. In the present study, the quantitative methods are used to present the data analyzed results. In order to analyze the questionnaire data, SPSS software using a one-dimensional Kolmogorov-Smirnov test [K - S] was used.

\section{Theoretical Background and Contexts}

All universities are now been defined not simply within the context of national borders, but on a global level. On this subject, understanding what it means to be world class is specifically fundamental to the future visions and strategies of higher education institutions establishment across the world. A case study of the research (e.g. Marginson, 2011a) and other relevant literature (Hazelkorn, 2008 \& 2011) assures that the wish of the world-class university status is prevalent.

World-Class Universities are generally perceived as universal. Most esteemed research universities are indispensable in developing a nation's competitiveness in the global knowledge economy. In the past decade, the development of World-Class Universities is considered a priority on the policy agenda of diversified stakeholders across the globe. A variety of reforms and development strategies at both national and institutional levels have been defined and observed. This policy concern has also been strengthened and intensified with the propagation of international league tables (Salmi, 2009; King, 2011). 
However, universities are located in different higher education systems and are bounded by a range of cultural, social and historical origins, and conditions. How do different countries and regions develop World-Class Universities? Are they confronting similar issues and challenges? Can effective experiences and strategies in one country be transferred to other national contexts? The Fourth International Conference on World-Class Universities, held in November 2011 in Shanghai, made an attempt to examine and review these questions and issues. In this section, the concept of world-class university and its critical features and characteristics were defined.

\section{The Concept of World-Class University}

The concept of world-class university, a term adopted broadly and interchangeably with global research universities or flagship universities, has been powerfully enclosed in governmental and institutional policies to advance national competitiveness in a progressively globalized world. However, the contradiction is that the concept has been extensively employed without a specific clear definition. Philip Altbach (2004) observed the paradox of the search for a - world-class university thus: - "everyone wants one, no one knows what it is, and no one knows how to get one."

In the past decade, the term "World-Class University" has been used to depict research universities on the peak of the higher education hierarchy (Salmi, 2011, p. 323). What then is a global research university? Its qualities have been described by Altbach \& Salmi (2011) and Salmi (2009). Thus, it must be internationally networked and internationally recognized and effective in the local, national, and global action. Moreover, it must encompass a global research competence and outputs in numerous fields, and maintain staff qualified for interpreting and applying findings in most fields of knowledge. Furthermore, it needs to have a practicable local doctoral program in some fields. These days, as a result of the broadening of aspirations, the research university functions of knowledge creation, distribution, storage and transmission, and also research training, are now extending from a limited group of nations to the majority of nations. Above all, it has research capacity to adequately create globally substantial output in both sciences and social sciences.

Altbach argued that "everyone wants one, no one knows what it is, and no one knows how to get one." It is generally agreed that World-Class Universities are academic institutions committed to generating and circulating knowledge in a variety of disciplines and fields, presenting elite education at all levels, serving national needs, and promoting the international public good (Altbach, 2009; Liu, 2009). Salmi (2009, pp.3-4) states that: 
"In the past decade, the term "world-class university" has become a catch phrase, not simply for improving the quality of learning and research in higher education, but also more important, for developing the capacity to compete in the global higher education market place through the acquisition, adaptation, and creation of advanced knowledge."

Among scholars, institutional administrators, and policy-makers, one of the common strategic alternatives to defining "World-Class" is through the formation and constant development of league tables. These league tables include the Academic Ranking of World Universities (ARWU) by Shanghai Jiao Tong University, the Times Higher Education World University Ranking, and the QS World University Rankings. In spite of diverse methodologies being used in evaluating universities in the international rankings, it is not confusing to detect that these indicators concentrate deeply on the quality of education, internationalization, research output, prestige, and impact (Salmi, 2009).

Ramakrishna (2012) opines that world-class universities have seven essential elements: 1) Have international curriculum; 2) Enlarge the student exchange; 3) Increase the international students' registration; 4) Emphasize the development of faculty and professors' communication; 5) Makes use of information technology; 6) Strengthen the collaboration with foreign institutions; and 7) Facilitate progress in the international development process.

For any university to become a WCU, there are three criteria to be fulfilled. These are:-

1. The University academics and students should publish their research in refereed journals and those articles should be cited by other researchers;

2. The University should have an international academic and student community; and

3. The University should produce globally employable graduates.

Nevertheless, to me, a World-Class University is a term of great complexity and it puts forward the notion of "academic excellence" or "appraising university quality". On the other hand, excellence in the same University functions is considered. Thus, it has three main roles: 1) Excellence in the education and research; 2) Developing and disseminating of knowledge; and 3) The pursuit of cultural and scientific activities, as well as social and civil life. 


\section{The Fundamental Features and Characteristics of World-class University}

The literature has tackled defining the fundamental features of worldclass university in a range of ways (The Russell Group of Universities (2012)). These include:

1. Relative performance against a set of measures (for example, ranking within league tables).

2. Presentation of specific critical success factors.

3. Delivery of a range of specific outputs and too many benefits.

These strategic alternatives are interconnected. For example, a worldclass university may perhaps make clear critical success factors which permit it to deliver a wide range of outputs and benefits.

\section{Relative Performance Measures}

1. The capability to compare different universities, within and across countries, is imperative to a wide range of stakeholders including students, business, policymakers, and academics. However, World-Class Universities success has to do with the spreading out of knowledge and the shaping of minds. These things are essentially very difficult to quantify or measure. Consequently, the performance and reputation of any world-class university cannot eventually be judged statistically, or measured in simple terms.

2. Rankings within league tables are continuously used as a tool for making comparisons, and are produced by a variety of different organizations, including the media and academic research organizations. International league tables include the Times Higher Education World University Rankings, Academic Ranking of World Universities (the Shanghai Index), and QS World University Rankings. Thus, these tables compare institutions according to various different factors. Also, it presents a snapshot of the comparative performance of universities, countries, and regions.

\section{Specific Critical Success Factors}

An alternative strategic alternative to defining a world-class university is to examine the important success factors which a world-class university demonstrates. A World Bank (Salmi, 2009) report suggests that there are three inter-related crucial success factors which distinguish a worldclass university from other universities. They are:

1. A high accumulation of talent, both faculty and students.

2. Adequate resources to grant an extensive, all-embracing learning environment, and a rich environment for advanced research.

3. Constructive governance to support autonomy, strategic vision, innovation, efficient resource management, and flexibility. 


\section{Range of Specific Outputs and Wider Benefits Research}

- Creating economic and social effects through enormous volume of excellent, leading research.

- Dealing with universal challenges through promoting and facilitating multidisciplinary research.

- Providing international leadership, advising governments, business, media, and accessing the latest cutting-edge breakthroughs in research.

\section{Knowledge Exchange} activity.

- Forming high-tech innovation clusters of knowledge rigorous

- Attracting investment from business and international sources.

- Making use of the findings of research and technological breakthroughs.

\section{Learning and Teaching}

- Producing extremely skilled, employable graduates, and postgraduates through the delivery of high-quality research-led teaching and supervision.

Li, Whalley, Zhang, \& Zhao (2008) believe that there are four features that are essential factors in achieving world-class university. They include:

A. Commitment to excellence in all university areas.

B. Taking part in the state-of-the-art and most advanced researches. Also, it entails regarding the influential and meaningful communication between education and research.

C. Researchers' freedom

D. They have permeable borders. This kind of university view is beyond the borders. Also, it cooperates with the industry through open interdisciplinary of education and research.

Sharma (2011) in a study titled "How to build a world-class university?" stated that World-class universities have three main characteristics. The first characteristic is the emphasis on talent. Actually, the poorness or richness, smallness or largeness, of the countries is not significant. The second characteristic is the high cost of this type of university. In fact, the creation of a world-class university cost millions of dollars. Saudi Arabia in 2007 spent tens of billions of dollars to establish Research University of graduate studies. Pakistan in establishing new universities of engineering, science and technology, allocated a budget of 750 million dollars for each one. Also, establishing Qatar University of Cornell Medical School cost 750 million dollars. The third characteristic are essential and important elements which include competitive environment, 
unlimited scientific research, scientific freedom, innovative thinking, innovation and creativity, academic freedom and high flexibility, and eliminating cumbersome rules.

Kerr (2001) about academic freedom said that there are four kinds of freedom. Therefore, this freedom is fundamental for world-class university. They are: 1) Freedom in creativity and innovation; 2) Freedom in order eliminate bureaucracy and needless limitation; 3) Freedom from subjective decisions of financing; and 4) Freedom with partners.

Alden \& Lin (2004) summarized the fundamental features and characteristics of world-class universities as follows:

1. Have an international reputation for its research;

2. Have an international reputation for its teaching;

3. Have a number of research stars and world leaders in their fields;

4. Are distinguished not only by other world-class universities, e.g., United States of America Ivy League, but also outside the world of higher education;

5. Have a number of world-class departments;

6. Identify and build on its research strengths and has a distinctive reputation and focus, e.g., its "lead" subjects;

7. Generate innovative ideas and produces basic and applied research abundantly;

8. Produce outstanding research output recognized by peers and prizes, e.g., Nobel Prize Winners;

9. Attract the most able students and produces the best graduates;

10. Can attract and keep the most excellent staff;

11. Can recruit staff and students from an international market;

12. Attract a high proportion of postgraduate students, both taught and research;

$13 . \quad$ Attract many students from overseas;

14. Operate within a global market and have international efforts in many activities, e.g., research links, student and staff exchanges;

15. Have a very reliable financial ground;

16. Receive large endowment capital and income;

17. Have diverse sources of income, e.g., government, private companies sector, research income, overseas student fees;

18. Provide a high quality and supportive research and educational environment for both its staff and students, e.g., high quality buildings and facilities/high quality campus;

19. Have an outstanding management team with strategic vision and implementation plans;

20. Produce graduates who end up in positions of influence and/or power, e.g., movers-and-shakers, e.g., Prime Ministers and Presidents; 
21. Often have a long history of best quality and outstanding achievement, e.g., Oxford and Cambridge in the United Kingdom and Harvard in the United States of America;

22. Make big contributions to society;

23. Has continuous benchmark with top universities and departments worldwide;

24. Have the confidence to set its own agenda.

\section{Alignment of Fundamental Characteristics of World-class University}

The superior fundamental aspects and characteristics of world-class university - highly sought graduates, leading-edge research, and dynamic technology transfer - can basically be attributed to three interconnected sets of factors (Salmi, 2009). These factors are: (a) a high concentration of talent (academics and students); (b) plentiful resources to offer a rich learning environment and support of advanced research; and (c) constructive governance features that encourage strategic vision, innovation, and flexibility. Thus, this thereby empower institutions to make decisions and manage resources without being held back by bureaucracy (Figure1). While the configuration of results-research, learning and technology transferdepends on the nature and precise mission of every single higher education institution (intensive research, teaching, applied science, etc.), the alignment of the three sets of factors is a requirement for any kind of institution.

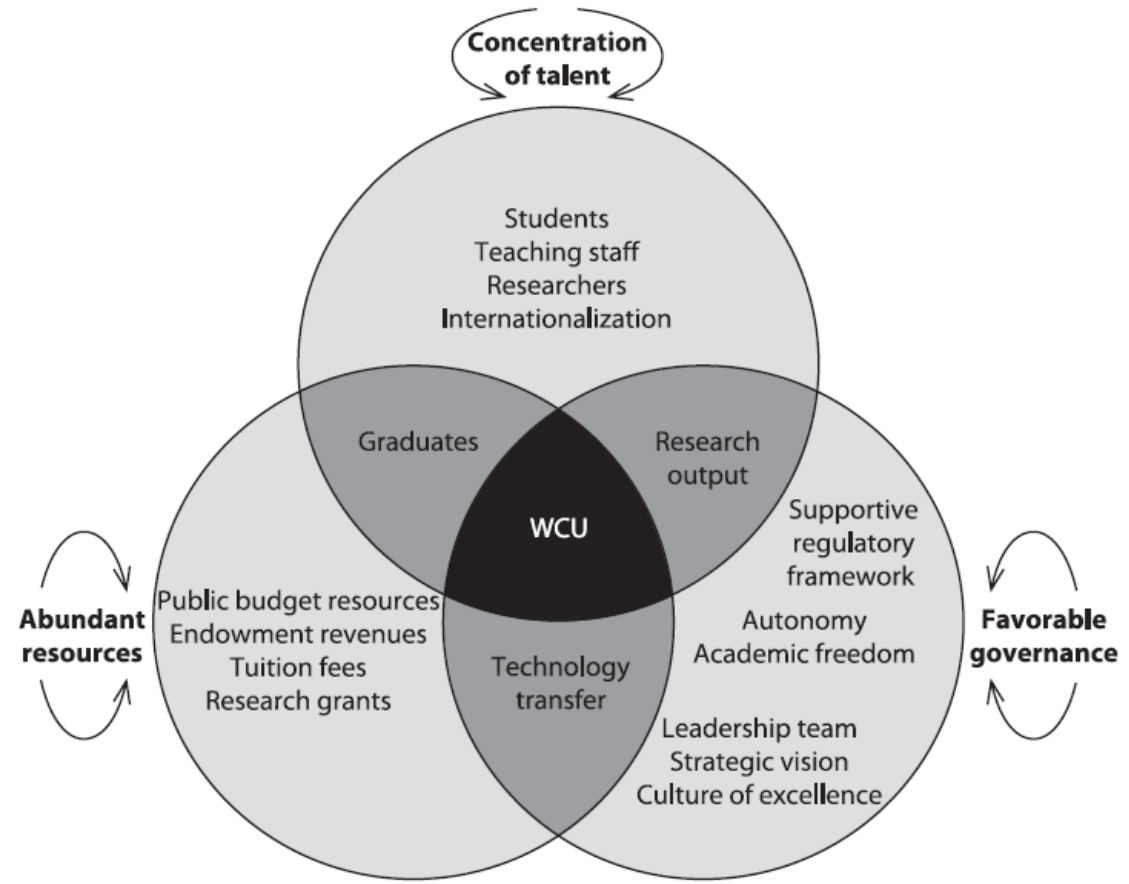

Figure 1. Characteristics of a world-class university (WCU): Alignment of Key Factors.

Source: Salmi (2013, p. 132). 
Salmi (2014) indicated that the first and maybe foremost determinant of academic excellence is the presence of a critical mass of top students and outstanding faculty. The most recognized universities internationally are able to select the best students and attract the best competent professors and researchers, not only from the country where they are situated but also globally.

Richness of resources is the second element that distinguishes wellperforming universities, notably in the case of research-intensive universities that depend upon state-of-the-art laboratories and equipment. These universities possess four chief sources of financing: government budget funding for functional expenditures and research, contract research from public organizations and private firms, the financial revenues created by endowments and gifts, and tuition fees.

The third element has to do with the degree that those universities have. World-class universities function in an environment that nurtures competitiveness, uncontrolled scientific inquiry, critical thinking, innovation, and creativity. Institutions that have considerable autonomy are also more adaptable because they are not bound by cumbersome bureaucracies and externally enforced standards. Nevertheless, the legitimate accountability strategic alternative do compel them. Consequently, they can manage their resources with responsiveness and quickly respond to the requests of a hastily changing international labor market. These autonomy elements are indispensable, though not adequate, to establish and maintain world-class universities. Other essential governance features are needed. These features include: having inspiring and determined leaders; having a strategic vision of where the institution is going; having a philosophy of success and excellence; and having a culture of continual reflection, organizational learning, and change.

Jamil's paradigm could be referred to as the World Bank paradigm because he imbeds the educational matters in the institution. There is no hesitation that his analysis is outstanding for establishing a world-class university globally. He, however, missed the realities in most developing economies. Favorable Governance, for instance, is vague in most failed States and remained suspicious in stabled and emerging developing nations like Egypt. There is absence of abundance resources because promises are normal at fanfares that celebrates opening of new universities. The culture of donation is commonly missing, and where it exists, corrupt officials use the opportunity to become billionaires. In addition, there is a continuous dichotomy between faculty, staff, and students. 
It should be noted that the World Bank report on the subject and its definition of world paradigm for categorization of an institution is biased and not completely adaptable in various parts of the world. To the World Bank,

"All world-class universities are research universities, and they always play a critical role within the tertiary education system in training the professionals, scientists and researchers needed for the economic development and generating new knowledge in support of the national innovation system” (World Bank, 2002).

\section{Theory of Change within Higher Education Institutions}

Salmi (2014) pointed out that the above framework can be complemented by a theory of change as represented in Figure 2. The theory of change encompasses two dimensions. First, it identifies and classifies institutional-level factors that influence the performance and sustainability of higher education institutions by directly influencing their strategic alternative of operation. Second, it represents the inputs and intermediate results that are consistent with the literature and global experience. Therefore, this leads to better graduates and research.

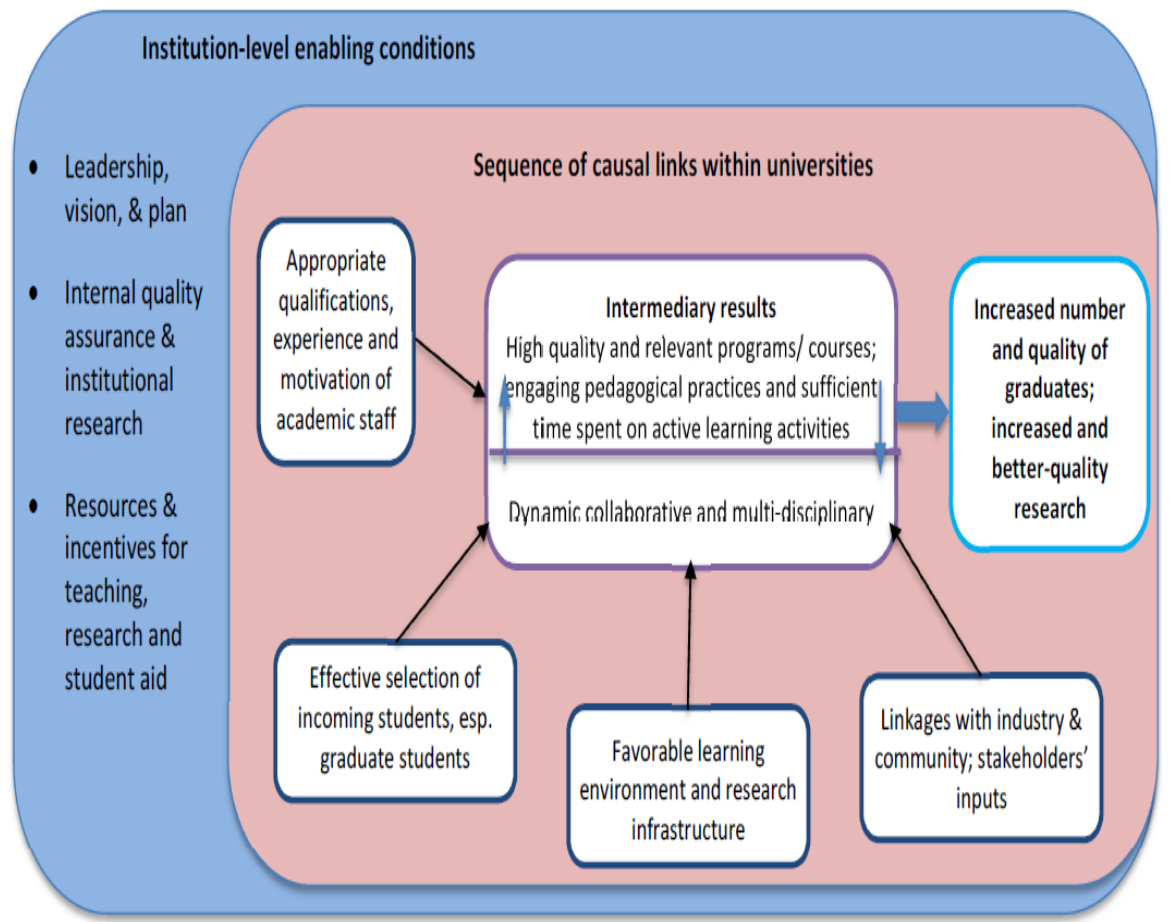

Figure 2. Theory of change for producing well-qualified graduates and high quality research Source: Salmi (2014). 
The most significant dimensions in the causal chain describing the performance of any higher education institutions comprises of the following aspects (Salmi, 2014):

- $\quad$ Academic preparation and enthusiasm of incoming students;

- Qualifications, experience, and motivation of academic staff influenced, in turn, by institutional recruitment policies, faculty capacity building programs, and inducements systems;

- $\quad$ Existence of close connections with employers and the community to develop the relevance of students' learning experiences and make sure that university research is adjusted to the resolution of priority economic and social problems;

- $\quad$ Learning environment and research infrastructure;

\section{Higher Education Ecosystem and World-class University}

The unsurpassed universities in the world, or in a country, do not function in a vacuum. A full assessment cannot be made without taking into consideration some noteworthy external factors of what could be called the higher education ecosystem. As illustrated in Figure 3, the foremost dimensions of the ecosystem comprises of the following elements (Salmi, 2011):

- Macro Environment: The political and economic status quo of the country, accompanied by the rule of law and respect for essential freedoms among those who exert influence, particularly, on the governance of higher education institutions (selection of university leaders), their level of funding, academic freedom, and safety for individuals.

- Leadership at the National Level: Vision and strategic plan to shape and direct the future of higher education and the technical and political competency to carry out the necessary reforms.

- Governance and Regulatory Framework: Governance structures and processes at the national and institutional levels that decide the degree of autonomy, as well as accountability methods.

- Quality Assurance System: The institutional agenda and the tools for assessing and supporting the quality of research, teaching, and learning.

- Resources and Financial Incentives: The existing resources to fund higher education and the methods used to assign these resources.

- Location: The quality of the setting and infrastructure, which allows the university to attract the best scholars and talented students.

- Digital and Telecommunications Infrastructure: The obtainability of a broadband connection. 


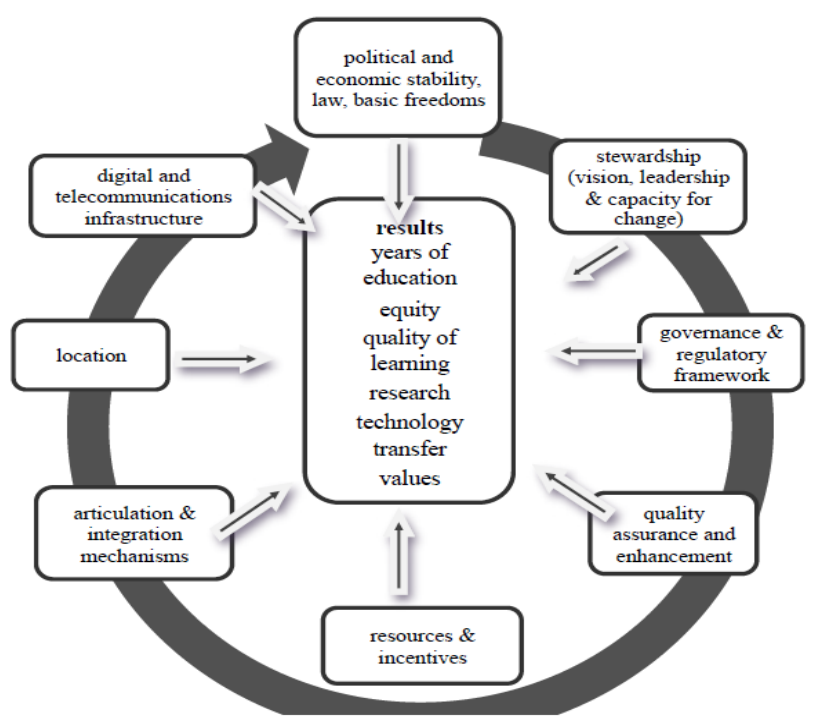

Factors determining university's performance

Figure 3. Understanding how the ecosystem influences the performance of top universities. Source: Salmi (2011b, p.336).

Salmi (2011b) reached a significant new finding from the case studies on the weight of the higher education ecosystem in influencing the performance of universities searching for accomplishing world-class status. A range of features of the ecosystem-from the macroeconomic and political situation to essential dimensions of governance to resource mobilization and allocation to location and the digital infrastructure-have a powerful influence on the capability of universities to achieve progress on the road to world-class universities .

\section{Egyptian Universities in the World's Rankings}

ARWU 2009: No Egyptian University among top 500

ARWU 2013: Cairo University (401-500)

ARWU 2014: Cairo University (358-500)

Table 1. Top 10 universities in Egypt

\begin{tabular}{|c|c|c|}
\hline 1 & 592 & Cairo University \\
\hline 2 & 1113 & Mansoura University \\
\hline 3 & 1229 & American University in Cairo \\
\hline 4 & 1244 & Benha University \\
\hline 5 & 1248 & Alexandria University \\
\hline 6 & 1547 & Kafrelsheikh University \\
\hline 7 & 1551 & Zagazig University \\
\hline 8 & 1557 & Ain Shams University \\
\hline 9 & 1640 & Assiut University \\
\hline 10 & 1969 & South Valley University \\
\hline
\end{tabular}

(Source: ARWU, 2015) 
Table 2. Top universities in the Arab Region

\begin{tabular}{|c|c|c|}
\hline 1 & 289 & King Saud University \\
\hline 2 & 592 & Cairo University \\
\hline 3 & 607 & King Abdulaziz University \\
\hline 4 & 821 & King Fahd University of Petroleum \& Minerals \\
\hline 5 & 931 & American University of Beirut \\
\hline 6 & 964 & King Abdullah University of Science \& Technology \\
\hline 7 & 1010 & University of Jordan \\
\hline 8 & 1040 & United Arab Emirates University \\
\hline 9 & 1113 & Mansoura University \\
\hline 10 & 1229 & American University in Cairo \\
\hline
\end{tabular}

(Source: ARWU, 2015)

Table 3. Top 10 WCUs in the World

\begin{tabular}{|c|c|}
\hline World Ranking & University \\
\hline 1 & Harvard University \\
\hline 2 & Stanford University \\
\hline 3 & Massachusetts Institute of Technology (MIT) \\
\hline 4 & University of California-Berkeley \\
\hline 5 & Cornell University \\
\hline 6 & University of Michigan \\
\hline 7 & University of Washington \\
\hline 8 & University of Wisconsin Madison \\
\hline 9 & University of Pennsylvania \\
\hline 10 & Columbia University New York \\
\hline
\end{tabular}

(Source: ARWU, 2015)

Therefore, the next section of the study aims to provide an overview of the present performance, problems, and challenges of the Egyptian higher education system. It also aims to identify existing issues and challenges. Secondly, on the basis of this diagnosis, it explores the main reforms and policy options that could be considered in order to address the problem at hand, that is, in developing World-Class Universities in Egypt.

\section{Overview of the Present Problems and Challenges of the Egyptian Higher Education System}

The higher education system in Egypt is made up of 23 public universities (established and run by the government), 22 private universities, 131 private higher institutes (established and run by private consortiums sometimes in collaboration with foreign higher education colleges or universities, e.g., the British or German or Russian universities), and 150 private higher education institutes (established and run by non-governmental organizations). Students also have the choice to obtain degrees from the Workers University Al-Azhar University (in which enrollment is limited to graduates of the Al-Azhar school system) and the Egyptian E-Learning University. Alternatively, students can join the open learning programs 
offered by a number of public universities (e.g., Cairo university has many open learning programs in the liberal arts) (Barsoum, 2014). Subsequently, gross enrollment rates in higher education are expected to expand from $28 \%$ to $35 \%$ by 2021 due to the increasing demand for higher education (OECD \& World Bank, 2010).

Owing to their inadequate institutional capacity and the design of their governance structures, higher education institutions in Egypt is not well positioned to deliver high quality instruction. The latest Global Competitiveness ranking (2015-2016) compiled by the World Economic Forum (WEF) ranks Egypt $116^{\text {th }}$ out of 140 countries in terms of the overall competitiveness of its institutions and higher education policies (Schwab, 2015). Egypt's ranking actually fell since 2012-2013. In generally having an institutional environment that is inadequately competitive, Egypt also performs poorly in terms of its higher education and training competitiveness, where it also ranks $116^{\text {th }}$ (Schwab, 2015).

However, higher education is also failing to provide the majority of students with better job prospects. The higher education system suffers generally and essentially from lack of autonomy, and is extremely centralized across various state authorities and several levels of control (OECD \& World Bank, 2010). Like many countries in the Arab region, Egyptian higher education institutions function under a very centralized control system and strict bureaucracies. The lack of autonomy is thus linked with the lack of academic freedom, lack of partaking in decision-making, and the lack of accountability and transparency. Lack of autonomy is also due to "the control of the Higher Council for Universities over academic policies”, "lack of transparency”, and "poor public relations”.

Higher education institutions are administered as extensions of state authority (Wilkens, 2011). For example, university presidents were mainly selected for their loyalty to the governing party, although this has changed since the January 25th 2011 revolution (Lindsey, 2012). The state-dominated strategic alternative has led to many dysfunctions in the higher education system including stifled institutional autonomy, partial flexibility, inflexibility of education and training programs, and more relevantly, weak responsiveness to student demands, the needs of the labor market, and the national development goals (OECD \& World Bank, 2010). This lack of autonomy and self-management continues to produce a mismatch in the demand and supply of skills in the Egyptian labor market, which is challenging for both graduates and employers (OECD \& World Bank, 2010).

Despite the fact that public spending on higher education is to a certain extent high in Egypt, due to the higher education expansion policies, public institutions are extremely underfinanced in terms of faculty, infrastructure, equipment, and learning materials (OECD \& World Bank, 
2010). Budget allocation strategic alternatives are not performance-based, nor do they reveal the real needs of the higher education institutions or provide the incentives required to align their educational processes and programs with community needs and employers' expectations (OECD \& World Bank, 2010; Fahim \& Sami, 2010). Therefore, this public funding strategic alternative provides no financial stimulus for public institutions to use the already insufficient resources more efficiently and cost effectively (OECD \& World Bank, 2010). In addition, as in the most of the Arab world, levels of investment in research and development (R\&D) are very low, at less than 1 percent of GDP. Thus, there are few connections between higher education and business.

In addition, the Egyptian higher education system continues to be hampered by an old-fashioned framework of public administration in addition to a very fragmented and detailed legal Structure that allows for extreme state intervention. State agencies control the curriculum design, approval of new degrees, and admission of students. Like public higher education institutions, private programs are similarly loaded by numerous of the obstructive laws and regulations, which weaken the ability of the private sector in higher education (OECD \& World Bank, 2010). Students' admission to public and private higher education institutions is exclusively based on secondary school examinations and centrally administered by the Central Placement Office. This admission process gives no institutional autonomy or flexibility for higher education institutions to integrate their missions and capacities into their admissions (OECD \& World Bank, 2010).

Computer labs, scientific equipment, and library books are benefits that not all universities benefit from (Salmi, 1992; Shann, 1992). Even when resources are existing, they are less spread such that they have slight influence. Most Egyptian universities and higher institutions are underequipped. Thus, they do not have the essential scientific equipment or materials for experiments (Shann, 1992). Libraries in Egyptian universities are also in very poor condition. According to Mary Shann (1992), in the early 1990s, some universities had books that were 15 to 20 years old. Thus, the libraries in most public universities do not have the necessary funds to update their collections or provide online resources for their students.

Another challenge is the students' limited familiarity with topics outside their disciplines. College students in Egypt choose their specialization in their first year. Therefore, their choice is based on the students' scores on the General Secondary Education Certificate (Thanaweya a'Amma). Thus, they get bounded exposure to anything but their field of study. Another factor that limits the scope further is that the course professor is considered as the only source of knowledge. 
Assessment is another component behind the limited scope of students' knowledge. Universities in Egypt adopt the two-semester system. Each semester is ongoing for 17 weeks. 15 of them were spent in studies and 2 for semester examinations followed by a 2 week semester break. In order to graduate, students should be given a passing grade in all subjects. Students' assessment is graded on a four-rank scale: acceptable - good very good - excellent. Thus, this is decided by their total GPA over their four years of study. Generally, Egyptian universities implement assessment methods which concentrate on the final evaluation limited to measuring knowledge attainment. They do not have standardized techniques and modern methods in evaluation (El Amine, 2014). In most western universities, course assessment is wide-ranging and would integrate multiple instruments such as quizzes, assignments, midterms, and presentations. In Egyptian public universities, conversely, assessment usually takes the form of an end of semester exam that represents 100 percent of the final grade. Therefore, this is controlled by faculty policies, except for some faculties which have practical, oral, and written exams.

Academic freedom in Egypt is a foremost concern in the contemporary higher education system. This dispute of academic freedom influences both the students and the faculty in public and private universities similarly (Reading Between the 'Red Lines' 2005). Enforced by diverse entities, students, faculty members and institutions suffer from the lack of academic freedom. In most Egyptian educational institutions, academic freedom is almost absent. The government of Egypt has established a comprehensive system to guarantee full control on the academic environment, starting with the presence of university police, to exhaustive rules and regulations, and to the political appointment of university presidents and deans (Reading between the 'Red Lines', 2005). This control extends to student activities, represented in suppression of student unions, student clubs, and student publications. However, the government, through the university president and faculty deans, reviews and controls all course objectives, materials, and outcomes (Reading Between the 'Red Lines', 2005).

The absence of a public accountability system, the predominance of a top-down authority strategic alternative which lays the grounds for the university's subordination to higher authorities, and the lack of partnerships with local communities or the inadequacy in existing ones are additional foremost concerns.

Generally, public universities are self-sufficient in terms of the number of faculty members they have in diverse fields of specializations. However, information on the quality of this faculty is missing. Student/teacher ratio is acceptable (20 to 30 students per faculty member). 
Some general trends which have been noticed are the deficiency of teachers in some specializations. This deficiency might occur due to shortage in numbers, to some favoring work in the private sector, to low wages, and to lending and transferring to developed or rich countries, especially as in the Gulf (El Amine, 2014).

\section{Higher Education Reform in Egypt}

In recent years, the Government of Egypt has driven chief reforms for modernizing the country. Moreover, the success of this effort depends profoundly on the quality of education and the skills of the population. Accessibility and lifelong learning in Egypt is going through the second phase of its Higher Education Reform plan. The first phase started in 2003 and ended in 2008. The second phase started in January 2009 and will continue for 4 years. The academic society is inspired by the January $25^{\text {th }}$, 2011 revolution. Therefore, they are hoping for a radical reform. Some constructive steps have taken place such as free elections of student unions, and electing, for the first time, the universities' presidents. How and whether or not change will continue is still a question that only time can give an answer to.

Consequently, the government has embarked on a long term program that keeps on until 2017. The aim of this program is to raise the level of efficiency by granting universities more autonomy in the modernization of their curricula and in the allocation of their internal resources. Egyptian Ministry of Higher Education has indicated that the plans which began to be implemented before the revolution are continuing as planned without any significant changes in the post-revolutionary period. Since the revolution, the ministry has, however, been undergoing continuous changes in its structure and personnel. As a result, this has caused some lack of progress in the policy design and its implementation (Rezk; Katarína, 2012). The main objectives of higher education reform in Egypt can be summarized as follows:

1. To increase the opportunities for higher education in Egypt.

2. To assure a quality educated graduate and strong research-based highly ranked academic institutions.

3. To motivate stakeholders to continuously improve, modernize, and finance the higher education institutions and programs.

4. To enhance the creativity and innovation skills of young generation to lead and advance the production and service sectors in the economic development plans.

5. To prepare HEI's and programs to be attractive for expatriates from neighboring countries to come and study in Egypt.

6. To foster the use of technology, and facilitate lifelong learning. 
7. To develop - to the highest possible level - technical education and vocational training.

\section{Lifelong Learning}

The way to guarantee practicality and implementation of lifelong learning concept is to provide enough opportunities through formal and non-formal education and training programs with appropriate requirements for enrollment. The success of such programs is governed mostly by the government formal effort in ensuring the following (Helal, 2014):

- $\quad$ Providing educational and training programs in diversified fields and disciplines.

- $\quad$ Reducing restrictions of age or program duration.

- Subsidizing these programs such that cost may not be a preventive factor for enrolment.

- Recognition of the degrees and certificates resulting from such programs.

- Providing multiple access to individuals with good reasons for re-entry.

\section{Equity}

Egypt has continuously been keen to preserve equity among citizens in higher education. Urban and rural area equity has been taken into consideration in the strategic master plan of higher education in Egypt. Gender equity is guaranteed by the central admission system to all public and private universities in which only the GPA in high school exam (Thanawya Amma) is the essential factor. In fact, there are other faculties that accept only girls (Faculty of girls in Ain Shams University, and to most recently all faculties of nursing). The result is that many colleges (e.g. Medicine, Pharmacy, Science, and of course Art and literature) have more female students than male students.

\section{Monitoring and Control System}

According to the Law No. 52 issued in 1970, the Ministry of Higher Education has the right to supervise all the activities of institutions, such as educational matters, financial procedures, organizational functions, and the like. However, the Ministry did not put this right into effect until 2013. This monitoring system was set up and operated by the Ministerial Decree No. 446 dated February 19, 2013. It involves executing systematic visits to the institutes by reviewers appointed by the Ministry. 


\section{Applying Quality Assurance Measures and Seeking Accreditation in Higher Education Institutes}

The Egyptian government has appreciated the need for maintaining quality in higher education programs to assure suitable and competitive qualification for the graduates. To guarantee this, Projects Management Unit (PMU) was established in 2002 after the National Conference for Education Development. Thus, this was intend to reform higher education in Egypt and address the 21st century challenges as stated in the Bologna process principles (1999) and in Prague (2001). It is a special unit working within the Ministry of Higher Education in Egypt reporting directly to the Minister of Higher Education. One of the fundamental projects that PMU has worked on was "Continuous Improvement and Qualifying for Accreditation, CIQAP." The aim of this project was to grant technical support, monitor, and evaluate the implementation of operational plans, which would lead to accreditation. PMU has, until November 2013, only worked with "Government Universities.” However, since 2013, all higher education institutions were given the opportunity to search for support from PMU (Ministerial Decree 4445, dated November 23, 2013). In addition, a new project was launched: Competitive Excellence Project of Higher Education Institutions (CEPHEI). This project seeks to increase the competitiveness of the Egyptian institutions of higher education in the international and regional job markets. The aims were stated by Elsayad (2014) as shown below:

- Advancing excellence and innovative practices in the fields of education, scientific research, and society services.

- Facilitating sustainable development of the financial resources of higher education institutions.

- Creating and activating the channels of communication with civil society organizations, and both national and international higher education providers.

A series of meetings to cultivate awareness took place in December 2013 to introduce the technical support scheme. Thus, representatives from all institutes attended those PMU meetings. Most institutes have now created a "Quality Assurance Unit" and are beginning to apply the accreditation requirements.

Strategic planning for higher education institutions is an additional reform initiative introduced in an endeavor to deal with the issue of quality in education. These strategic plans were drawn to identify specialties needed, and the geographic locations for new campuses. Student admissions for 2013-2014 were based on the number of faculty members and the surface area of educational facilities within each institute (Decree by Council of Higher Education Institutes at 29-1-2013 meeting). The Council of Higher 
Education agreed upon a plan to increase the faculty/student ratio for each educational specialty as shown in Table 3.

Table 3. Approved Plan for Faculty/Student Ratio for Educational Specialties and Future Academic Years

\begin{tabular}{|c|c|c|c|}
\hline Educational Specialty & $\mathbf{2 0 1 3 - 2 0 1 4}$ & $\mathbf{2 0 1 4 - 2 0 1 5}$ & $\mathbf{2 0 1 5 - 2 0 1 6}$ \\
\hline $\begin{array}{c}\text { Applied arts, engineering, agriculture, } \\
\text { and nursing }\end{array}$ & $1: 75$ & $1: 60$ & $1: 50$ \\
\hline Mass communication, liberal arts & $1: 100$ & $1: 80$ & $1: 60$ \\
\hline $\begin{array}{c}\text { Social work, hotel and tourism, and } \\
\text { business }\end{array}$ & $1: 150$ & $1: 120$ & $1: 100$ \\
\hline
\end{tabular}

Subsequently, there were other decrees issued during the year 2013 that aimed to improve the quality of education in higher education institutions as follows (Elsayad, 2014):

- $\quad$ Ministerial Decree No. 446 dated 19-2-2013 declared the need to establish a strict system for monitoring and controlling the education process in all higher education institutes.

- $\quad$ Ministerial Decree No. 1945, dated 31-7-2013, made it obligatory for institutes to qualify for institutional and program accreditation. This was followed by Ministerial Decree 4445, dated 23-11-2013, which instructed institutes to seek technical support from the Projects Management Unit in the Ministry of Higher Education, in order to qualify for accreditation.

The National Authority for Quality Assurance and the Accreditation of Education was established in 2006. The aim of this body is to evaluate both the instructional process and the institutional capability of schools for accreditation.

\section{Financing}

The Egyptian government recognizes the deficiencies of the recent system, and has taken steps to gather additional funding for public universities. For instance, to deal with the issues of efficiency, the government has tentatively attempted to apply cost sharing to special programs in public universities. It has also attempted to link academic staff salary with the level of performance. In addition, the government has encouraged the private provision of higher education so as to meet the challenges of increased future demand for higher education (Fahim, 2009).

\section{Competitiveness}

In recent times, Egypt has always been the center for education in the Arab world and in some African countries. It is now expanding its education programs across the borders to reach gulf countries. Egyptian higher education institutions are opening education facilities in some Arab gulf states. Higher education reform plans in Egypt are considering the 
competition of other higher education institutions in the region in terms of quality, cost, and flexibility.

\section{Internationalization}

Internationalization is a foremost criterion for higher education reform in Egypt which is open up for international interaction and recognition. This criterion requires collaboration with other international higher education institutions through exchange programs, joint degree, or double degree programs which will help in mutual recognition (Helal, 2014).

\section{E-learning}

E-learning has been broadly used as a tool in the learning process in most of the Egyptian universities. In spite of its importance, many of the academic staff in these universities still tends to avoid using it or they use it only to upload materials, but disregard the interactive activities offered by such systems (El-Seoud, 2013). The Egyptian government reform initiatives to tackle the issue of E-learning has established the National e-Learning Center (NELC) to serve as a technical unit within the Supreme Council of Universities to promote and support the development of e-learning in Egypt. This is possible by improving the development of the learning content to the highest maturity level so as to achieve strong presence both locally and regionally. Another initiative to support E-learning in Egyptian universities is the Information and Communication Technology Project (ICTP) that contains five sub- components at a wide level, as well as activities at the university level to address quality and efficiency related issues. These subcomponents include: Network Infrastructure, Management Information System, (MIS), e-learning, Digital Libraries, and ICT training (ICTP, 2008).

\section{The Requirements of Transferring Public Egyptian Universities to World-class Universities \\ Two Different Perspectives and Two Dimensions}

1. Universities function in both national and global contexts. The worldclass idea falls into the international sphere. It presumes that the university is contesting with the best academic institutions in the globe and is aspiring to the peak of excellence and recognition. National and regional realities may be at variance. They have to do with the need of the immediate society and economy, and indicate responsiveness to local communities. In these contexts, the nature of academic performance and roles may be different from what is expected at institutions contesting in the global realm. To label one sphere world class while relegating the others to the nether regions of the academic hierarchy is perhaps inevitable, but nonetheless unfortunate. 
2. Two interdependent and complementary perspectives need to be considered in examining how to establish new world-class universities. The first dimension, of an external nature, concerns the role of government at the national, state, and provincial levels. It also concerns the resources that can be made available to enhance the stature of institutions. The second dimension is internal. It has to do with the individual institutions themselves and the necessary evolution and steps that they need to take to transform themselves into world-class institutions.

\section{Government Role}

Recent international experience shows that three basic strategies can be followed to establish world-class universities:

- Governments could consider upgrading a small number of existing universities that have the potential for excelling (picking winners).

- Governments could encourage a number of existing institutions to merge and transform into a new university that would achieve the type of synergies corresponding to a world-class institution (hybrid formula).

- Governments could create new world-class universities from scratch (clean-slate strategic alternative) (Liu, Wang and Cheng, 2011).

-Government could bring the various universities under one umbrella to put join effort in the area of their own expertise to transform into WCU.

\section{Strategic Transfer Alternatives}

Regarding the provision of higher education infrastructure in order to upgrade the universities to world-class universities, there are four main strategic alternatives according to comparative and universal studies that were offered. Among these four, transfer strategic alternatives countries decide to establish world-class universities by upgrading or merging existing ones. Hence, they must also choose an appropriate methodology during the selection of existing universities. According to Jamil Salmi (2014, 2013, 2011, 2010, 2009), there are four general models for building a WCU:-

\section{Upgrading Existing Institutions Strategic Alternative}

One of the foremost benefits of this strategic alternative is that the costs can be notably less than building new institutions from square one. This is the strategic alternative that is followed by China since the early 1980s, with a series of thoroughly targeted reforms and investment programs. However, upgrading existing institutions is the less-expensive alternative, but is a challenge to reform and transform. In this strategic alternative, all the standards, indexes, and rules collected are based on comparative studies. They have gone through all social, philosophical, cultural, and political filtering. Therefore, to upgrade the current systems of 
Egyptian traditional universities by action plan, for example in a five-year period, in this case, it will provide a gradual upgrading of universities. In this process, all instructions, guidance, executive regulations and their related rules are prepared, designed, and implemented. Normally, the process of promotion and upgrading takes two or three decades depending on multitude concentration on the talents and financial resources able to consider, rule, and control the independence and academic freedom from the very beginning (Sharma, 2011).

\section{Merging Existing Institutions Strategic Alternative}

Another potential strategic alternative to establish a world-class university involves advancing mergers among existing institutions. Denmark and France have persistently adopted this strategic alternative in recent years. In spite of merging, existing institutions can present opportunities to modify organizational culture. Nevertheless, they are difficult to manage. Merging of existing universities in a new integrated system can be done through Joint Ventures and integration. In France, for example, different universities and grandes écoles are investigating the possibility of merging on a regional foundation. In Denmark, the government has encouraged setting up worldclass university through granting an innovation fund that would remunerate the combination of similar institutions. In China, some mergers have happened to strengthen existing institutions. For example, Beijing Medical University was combined with Beijing University in 2000. In the same way, in Shanghai, Fudan University combined with a medical university. In addition, Zhejiang University was the outcome of merging five different universities together. The immense benefit of merging different universities is the emergence of better institutions that have the ability to benefit from the new collaborations in terms of human and financial resources.

\section{Creation of New Institutions Strategic Alternatives}

Although creating new institutions from scratch grant the ultimate opportunities to actualize a culture of excellence and make a selection of the best staff, it is also at the same time the most costly policy option. Sharma (2011) stated that establishing new institutions generally are done faster and more successful than upgrading. In this strategic alternative, two major actions must be done: 1) design the new university in relation to the standards of world class with the purpose of explaining the elements, objectives, comprehensive plan, and a specific road map with the international standards; and 2) The implementation and development process at this phase which takes two to five years, executive fields will be delivered, and the university will implement its programs according to international standards. 


\section{Collaborative Strategic Alternatives}

Collaborative strategic alternative is not only cost saving, but also grant opportunities to all the universities to have the chance to accomplish exceeding in their specific fields. As a consequence of this, a mixture option of upgrading and merging existing institutions can also be followed. The difficulty in merging is that one of the universities has to lose its identity. In addition, managing the required changes would be complicated and difficult. Collaborative strategic alternative can be put into operation at the national and international levels at the same time. To a great extent, this strategic alternative has been implemented in Japan and India. For multi-dimensional and faster development at lower money involvement, this strategic alternative is appropriate for the country.

Generally, there is no universal model for building up WCUs, just as there is no one ideal model for a WCU. Each country must choose a strategic alternative that is most suitable for itself.

The pros \& cons of each strategic alternative as discussed by Jamil (2006) are mentioned in Table 1.

Table 1. Costs and Benefits of strategic alternatives for establishing world-class Universities

\begin{tabular}{|c|c|c|c|c|}
\hline $\begin{array}{c}\text { Strategic } \\
\text { alternativ } \\
\mathbf{e}\end{array}$ & $\begin{array}{l}\text { Upgrading } \\
\text { Existing } \\
\text { Institutions }\end{array}$ & $\begin{array}{l}\text { Merging Existing } \\
\text { Institutions }\end{array}$ & $\begin{array}{l}\text { Creation New } \\
\text { Institutions }\end{array}$ & $\begin{array}{l}\text { Collaborative } \\
\text { Strategic } \\
\text { Alternative }\end{array}$ \\
\hline $\begin{array}{c}\text { Ability to } \\
\text { Attract } \\
\text { Talent }\end{array}$ & $\begin{array}{l}\text { Difficu } \\
\text { lt to keep the } \\
\text { top staff and } \\
\text { change the } \\
\text { brand to } \\
\text { attract best } \\
\text { students. }\end{array}$ & $\begin{array}{l}\text { Opportun } \\
\text { ity to transform } \\
\text { the leadership } \\
\text { and to attract } \\
\text { new staff. } \\
\text { Current } \\
\text { staff may } \\
\text { oppose. }\end{array}$ & $\begin{array}{c}\text { - Opportun } \\
\text { ity to make a } \\
\text { selection of the } \\
\text { best (staff and } \\
\text { students). } \\
\text { - Complexi } \\
\text { ty in recruiting } \\
\text { top students to } \\
\text { “unknown” } \\
\text { institution. } \\
\text { - Need to } \\
\text { develop research } \\
\text { and teaching } \\
\text { traditions. }\end{array}$ & $\begin{array}{l}\text {-Opportunity } \\
\text { to make a } \\
\text { selection of } \\
\text { students in } \\
\text { wide-ranging } \\
\text { area of study. }\end{array}$ \\
\hline Costs & Less expensive & Neutral & More expensive & Less Expensive \\
\hline $\begin{array}{c}\text { Governan } \\
\text { ce }\end{array}$ & $\begin{array}{l}\text { Difficult to } \\
\text { change } \\
\text { Methods of } \\
\text { actions within } \\
\text { same governing } \\
\text { framework. }\end{array}$ & $\begin{array}{l}\text { - More probably } \\
\text { to work with } \\
\text { diverse legal } \\
\text { status than } \\
\text { existing } \\
\text { institutions. }\end{array}$ & $\begin{array}{l}\text { - Opportunity to } \\
\text { establish suitable } \\
\text { framework. }\end{array}$ & $\begin{array}{l}\text { - Difficult to } \\
\text { bring different } \\
\text { independent } \\
\text { institutions } \\
\text { under one } \\
\text { umbrella owing }\end{array}$ \\
\hline
\end{tabular}




\begin{tabular}{|c|c|c|c|c|}
\hline & & & & $\begin{array}{l}\text { to conflict of } \\
\text { interest. }\end{array}$ \\
\hline $\begin{array}{c}\text { Institution } \\
\text { al } \\
\text { Culture }\end{array}$ & $\begin{array}{l}\text { - Difficult to } \\
\text { transform from } \\
\text { within. }\end{array}$ & $\begin{array}{l}\text { - May be } \\
\text { problematic to } \\
\text { build a new } \\
\text { identity from } \\
\text { dissimilar } \\
\text { institutional } \\
\text { cultures. }\end{array}$ & $\begin{array}{l}\text { - Opportunity to } \\
\text { build culture of } \\
\text { excellence. }\end{array}$ & $\begin{array}{l}\text { - Difficult to } \\
\text { change existing } \\
\text { culture. }\end{array}$ \\
\hline $\begin{array}{l}\text { Change } \\
\text { Managem } \\
\text { ent }\end{array}$ & $\begin{array}{l}\text { - Foremost } \\
\text { consultation } \\
\text { and } \\
\text { communication } \\
\text { campaign with } \\
\text { all } \\
\text { stakeholders. }\end{array}$ & $\begin{array}{c}\text { "Normative" } \\
\text { strategic } \\
\text { alternative } \\
\text { to educate all } \\
\text { stakeholders about } \\
\text { proposed norms } \\
\text { and } \\
\text { institutional } \\
\text { culture. }\end{array}$ & $\begin{array}{l}\text { - "Environmental } \\
\text { adaptive” strategic } \\
\text { alternative } \\
\text { to communicate } \\
\text { and } \\
\text { socially market the } \\
\text { new institution. }\end{array}$ & $\begin{array}{l}\text { Diffic } \\
\text { ult to } \\
\text { implement } \\
\text { Lewin's } \\
\text { change } \\
\text { model. }\end{array}$ \\
\hline
\end{tabular}

Source: Salmi \& Liu (2011).

Therefore, it should be noted that these general strategic alternatives are not mutually incompatible. Also, countries may pursue a combination of strategies based on these strategic alternatives.

\section{Key Questions Needs to be Answered}

The establishment of a world-class university necessitates strong leadership, an exceptional vision of the institution's mission and goals, and an accurately articulated strategic plan to translate the vision into specific and tangible targets and programs. Universities that seek to achieve better results involve in an unbiased assessment of their strong points and areas for improvement, develop new spread out goals. Also, they design and implement a renewal plan that can lead to improved performance. The following strategic questions should to be answered by authorities, governments, and institutions to guide the pursuit in the direction of establishing world-class universities (Salmi \& Liu, 2011):-

\section{At the National Level}

1. Why does the country need a world-class university?

2. What is the economic justification and the expected added value compared with the contribution of existing universities?

3. How many world-class universities are required and affordable as a public sector investment?

4. What strategic alternative would do well in the country context: upgrading existing institutions, merging existing institutions, or creating new institutions? 
5. What should be the selection process among existing institutions if the first or second strategic alternative is selected?

6. What will be the relationship and communication process between the new institution(s) and existing higher education institutions?

7. How will the transformation process be financed?

8. What share should be financed from the public budget? What share should the private sector finance?

9. What incentives should be offered (for example, land grants and tax exemptions)?

10. What will the government's role be in this process?

\section{At the institutional level}

11. What is the vision for this university? What position will it keep?

12. What level of independence and models of accountability will be applicable?

13. What are the governance procedures that have got to be put in place to enable the transformation process and support appropriate management practices?

14. How can the institution build the best leadership team?

15. What are the vision, mission, and the goals that the university is seeking to accomplish?

16. In what niche(s) will the university seek excellence in teaching and research?

17. What is the target student's population?

18. What are the internationalization goals that the university needs to achieve (with

regard to students, faculty, programs, and so forth)?

19. What is the cost of the proposed qualitative leap, and how is it going to be funded?

20. How will success be measured?

21. What monitoring systems, outcome indicators, and accountability models will be used?

\section{The Challenges of Establishing World-class Universities}

There is no common formula or magic prescription for creating a world-class university. In addition, the transformation of the university system cannot happen in isolation from its context. A long-term vision for building world-class universities - and its implementation - should be thoroughly articulated with: (a) the country's economic and social development strategy, (b) progress changes and planned reforms at the lower levels of the education system, and (c) strategies for the development of different forms of higher education institutions to create a combined system of teaching, research, and technology-oriented institutions. Furthermore, 
Salmi (2010) emphasized that the most shared drawbacks came across in some of the current projects that is aimed at establishing a new world-class university are as follows:-

\section{Build a Marvelous Campus: Expect Magic to Come About}

The physical infrastructure is the most observable part of a new university. Usually, lots of attention is given to the design and construction of striking, up-to-date facilities. Definitely, up-to-date academic infrastructure is an essential element of the education experience of students. Therefore, researchers ask for adequate and well equipped laboratories to perform pioneering scientific inquiries. Nevertheless, without an appropriate governance system, charismatic leadership, a state-of-the-art curriculum, and well qualified academics, the marvelous campus will be like an empty building that includes a waste of precious resources.

\section{Design the Curriculum after Building-up the Facilities}

Teaching and learning can be adapted to the environment of the institution. This can be applied in the process of traditional teaching. Thus, world-class pedagogical practices require state-of-the-art facilities. For example, interactive learning, problem-based learning, teamwork, and peer learning may be discouraged by the physical constraints of conventional lecture classrooms.

\section{Import Content from Somewhere Else}

The teams who are responsible for building new universities have a tendency to look almost at the top-ranked institutions in developed countries to purchase or reproduce components of their curriculum, rather than designing their own programs according to labor market needs. Although this might give the impression of being practical, it is not the utmost successful technique of creating the academic culture of a high standard new university.

\section{Design with an OECD Ecosystem in Mind: Implemented Somewhere Else}

It is so challenging to create universities when the higher education ecosystem within which they function is not completely encouraging. Some of the highly imperative components of a positive ecosystem are the existence of charismatic leadership at the national level. This entails the presence of a vision about the future of higher education, and the ability to put reforms into action. The second component is the regulatory framework. The regulatory framework refers to the status of legal provisions, governance structure, and management processes at the national and institutional levels. 
The third component is the quality assurance framework. This framework involves the strategic alternatives and pathways incorporating a range of higher education institutions, the financial resources and incentives, as well as the electronic and telecommunications infrastructure. Therefore, all of these necessitate an all-embracing set of conditions to function appropriately. This is in connection with political and economic steadiness, the rule of law, the existence of essential freedoms, and a satisfactory location from the viewpoint of the local economic, social, and cultural life where the new higher education institution is meant to function. The nonexistence of a single one of these elements or the lack of alignment among these diverse dimensions probably compromises the capability of new universities to evolve and survive.

\section{Postponing the Introduction of the Board and Choosing the Leadership Team}

Establishing a new university is generally a political decision revealing a creative ambition at the highest levels. This certainly leads to a central controlled design and application process. The setting up of a new university necessitates the desire and determination to build a new organizational culture. Thus, it cannot be created by a disinterested committee. Setting up a new university is an enormous project that must be completely controlled and accomplished by a dynamic leadership team. This team works under the authority of an independent board that has the capability to offer guidance, authorization, and empowerment.

\section{Stack the Board with Political Representatives}

Founders require a guiding board that integrates a variety of essential expertise that can improve over time. Thus, the people who are appointed should represent an area of expertise that is needed in the management of the new institution.

\section{Plan for Up-front Capital Costs, but Pay Little Attention to Long-term Financial Sustainability}

The supporters of a new university normally indicate with interest, the enormous endowment devoted to the establishment of the new institution. Thus, the primary capital investment is a part of the entire project. It is critical to grant sufficiently for the first few years of application and to set-up a considerate business model that permits the new institution to develop and tolerate in a financially continuous manner.

\section{Be Extremely Ambitious in the Enrollment Objectives}


The managers of new institutions recurrently believe that they can quickly give access to great numbers of students. This is scarcely accomplished without sacrificing quality. It is normally a better idea to begin with a small number of programs and student body if quality is a priority.

\section{Believe that everything can be achieved in Eighteen Months}

A variation of overambitious planning is supposing that a new institution can be opened in a matter of months. Also, high quality teaching and research can be achieved within a few years of setting-up a new university. Actually, speedily moving through the preliminary phase of design and implementation will only frequently result in rushed decisions that can have a negative effect on the quality and expenditure of the project.

\section{Depend Completely on Foreign Academics without Creating Local Capacity}

Employing foreign academics is a normal action to speed-up the launch of a new university in an inadequate ability country. Actually, it is a good decision to hire experienced faculty and researchers to develop new programs. Therefore, it can also be a very efficient capacity-building strategy when a significant part of the mission of the foreign academics is to coach less experienced academics from the host country.

\section{Research Results}

The Findings of Question 2: 20 elements form world-class university. Thus, considering the characteristics of existing universities in Egypt, there is a gap between the depth of universal and current components of the Egyptian universities. This components and dimensions are as follows: 1) A high concentration of talent (academics and students); 2) The high cost of the world- class university; 3) Universal learning resources; 4) Competitive admission of students; 5) Scientific referencing and citation; 6) Multilingualism; 7) International students; 8) High rating and ranking; 9) Strategic vision; 10) Abundant resources to offer a rich learning environment and support advanced research; 11) Innovation and creativity; 12) High level of research activities; 13) Education quality; 14) Affordable and considerable income; 15) Administrative structure and supportive rules; 16) International, responsive, and innovative courses; 17) Information technology; 18) Collaboration with foreign institutions, industry, and the community; 19) Academic and managerial autonomy; and 20) Tolerance of cultural diversity.

\section{The Findings of Question 4}

According to the obtained results and because $\mathrm{Z}$ amount of Kolmogorov-Smirnov is between 1.86 to -1.96 , the community distribution 
is normal. In addition, the average of 3.2 was obtained. Therefore, by polling, we conclude that higher education experts consider that the Egyptian universities do not cope with international standards. Considering the findings about the obstacles, the essential significant problems and challenges include: language, research, infrastructure, the absence of a national program for the development of top institutions, as well as the lack of critical mass in terms of international scholars, the slow progress on the issue of internationalization, the governance model in public universities, lack of accountability, and the lack of public investment in scientific research capacities.

\section{How to Turn Barriers into Opportunities}

Language: The language necessitates continuing work and its problem to be institutionalized by education. However, solving this problem also necessitates prolonged act in elementary and secondary schools.

Research: Research is among the distinctive characteristic of the world-class university. However, in order to institutionalize the research in the Egyptian universities, it requires commercialization in the real world of industry. In this process, universities should take their programs toward basic and applied research.

The Infrastructure: Taking a look into the infrastructures, public and private universities should revise, reinvest, and use technology in a broad level.

Development of top universities involves that all the foremost stakeholders like government and private founders have a duty to continually present funds or generate competitive funds for teaching excellence, research, and community service. Furthermore, universities should detect the pathway for achieving its goals by developing a position for itself.

Internationalization: Universities should formulate strategies of diverse stages of aspiration, complexity, and duration. Carrying out these strategies requires dedication by top institutional leaders. It requires interest and enthusiasm by faculty, students, and other stakeholders. Also, it involves the establishment of a well-defined monitoring processes, and allocation of sufficient resources. Internationalization strategies are only as good as they present a transformational education for students and increase faculty scholarly engagement.

Governance Model: Universities autonomy should be granted by transforming universities from government institutions to independent ones. Universities have their own governing board with the power to take administrative and academic decisions. In addition to this, universities ought to establish boards of trustees with representatives from the government, alumni, industry, outstanding figures in education, and the academic 
community. The Board is the highest body in an autonomous university, and possesses the power to choose and appoint the rector. They approve the strategic plan, yearly programs, and the budget plan of the university. Also, great investment and changes in budget allocation have got to be approved by the Board. In addition, they are in charge of hiring the internal audit unit and the external auditor to lead external audits. The rector of the university is assisted by vice-rectors.

Investment in Scientific Research: Lack of fund or its insufficiency should not hinder scholarly production of pioneering researches that could generate inventions and publications across disciplines. Consequently, a scholarly research have to focus on filling the gap by previous publications, breaking a brand-new ground, or an appraisal of existing knowledge based on novel proof.

In this process, appropriate attention must also be directed to other barriers. It should be able to draw and predict transfer strategic alternatives from the unfavorable situation to favorable situation. Generally, polling frequency indicates: 31 individual in response to questions had agree, 17 individual agreed completely, and 9 individual have no comment. No experts disagree or strongly disagree.

\section{The Findings of Question 8}

After presenting transfer strategic alternatives [Upgrading existing institutions strategic alternative, Merging existing institutions strategic alternative, Creation of new institutions strategic alternative, Collaborative strategic alternative] and according the empirical results of the polling $\mathrm{N}=$ 57 and the cultures characteristics, $81 \%$ of experts were consentient on the first strategic alternative, 67\% agree on the second strategic alternative, $71 \%$ due to the extremely high cost agree to the establishment and creation of universities, and $91 \%$ of experts were consentient on the fourth strategic alternative.

\section{Discussion and Conclusion}

The motivation of world-class universities is not an artificial desire. Nevertheless, it totally sounds ambitious. However, a qualitative leap is required for Egyptian universities to enter the special group of world-class universities to support the economic development in Egypt as pillars of innovation. Some of the existing challenges of developing world-class universities in Egypt are language, research, infrastructure, the absence of a national program for the development of top institutions, as well as the lack of critical mass in terms of international scholars, the slow progress on the issue of internationalization, the governance model in public universities, a 
lack of accountability, and the lack of public investment in scientific research capacities.

In conclusion, the following areas need to be discussed further for decision making towards developing world-class universities in Egypt. The road to academic excellence is full of avoidable pitfalls, as explained in the previous discussion of most of the generally observed mistakes. More significantly, the decision to develop a world-class university must always be examined within the appropriate context to guarantee complete alignment with the national higher education strategy. With pragmatic and reasonable planning, however, reaching for excellence in higher education, at all levels, can be seen as an important and significant thing. On one hand, government need, consequently, to build an encouraging environment and develop the financing and regulatory conditions that assist and strengthen its universities to compete at an international level. Thus, this is done on a set of indicators in which the quality and relevance of university education are normally assessed including reputation, awards, foreign students and faculty, and research grants. On the other hand, universities pursuing to become worldclass institutions must formulate their own strategic plans and classify priorities to develop areas of excellence. However, these areas should be characterized by research results and groundbreaking and cutting-edge teaching. Moreover, alliances between Egyptian universities, with universities in other developed countries, and successfully use internationalization strategies, can be of assistance to speed-up the process of developing areas of excellence.

Improving the quality of the learning experience through a multicultural component is another imperative issue for Egypt to develop its world-class universities. Consequently, the expertise to present programs in a foreign language, particularly English, can be an influential attraction factor. Among the top 100 universities in the Shanghai ranking, 11 are from countries where the official language is not English, but where many graduate programs are presented in English (Denmark, Israel, Finland, Norway, Netherlands, Sweden, and Switzerland). Another important component is allocating resources within the university. Hence, this helps in supporting a quantitative and qualitative development in priority research areas by means of appropriate investment funds. This necessitates in turn a well-defined internal research development and monitoring strategy to describe the disciplinary and multi-disciplinary areas.

Collaborative strategic alternative is expected to be the most excellent strategic alternative as it is not only cost saving, but also present opportunities to all the current universities to take precedence in their respective fields. However, this means identifying and backing-up the lawful and complementary missions of Egyptian universities, provided that there are 
adaptable paths and bridges to make student progression possible between the variety and categories of institutions and programs. When all these conditions are met, Egypt can make the dream of having world-class universities a reality. In a country like Egypt, where the very substantial higher education reform of the last decade was adopted by the government, the world-class university development initiative must be a project that attains the consensus of the country as a whole.

\section{References:}

Alden \& Lin (2004). Benchmarking the Characteristics of a World-class university: Developing an International Strategy at University Level. London: The Leadership for Higher Education Foundation.

Altbach \& Salmi (Eds.) (2011). The Road to Academic Excellence: The Making of World-Class Research Universities. Washington: The World Bank.

Altbach (2004). The costs and benefits of world-class universities. Academe, 90(1), 20-23.

Altbach (2007). Higher Education in the new century: global challenges and innovative ideas. Boston College.

Altbach (2011). The past, present and future of the research university. In P. Altbach \& Salmi (Eds.), The Road to Academic Excellence: The Making of World-Class Research Universities (pp. 11-32). Washington: The World Bank.

Barsoum (2014). Aligning incentives to reforming higher education in Egypt: The Role of private institutions. Economic Research Forum Working Paper Series. Cairo, Egypt.

Bellon (2005). Can ranking ambition learn from evaluation practices and methodologies? In N. C. Liu (Ed.), Proceedings of the First International Conference on World-Class Universities (WCU-1), June 16-18, 2005, Shanghai, China (pp. 51-66).

Central Agency for Public Mobilization and Statistics (CAMPAS) (2013). Poverty Indicators Based on In-come, Expenditure and Consumerism, Cairo: CAMPAS.

Clark (1998). Creating entrepreneurial universities: Organizational pathways Paris: International Association of Universities and Elsevier Science.

Clark (2004). Delineating the character of the entrepreneurial university. Higher Education Policy, 17, 355-370.

Collins (2001). From Good to Great: Why Some Companies Make the Leap and Others Don't. New York: Harper Business.

Council of Higher Education Institutes (CHEI) (2013). Minutes of 29 January 2013 Meeting. Cairo: CHEI. 
Denmark (2007). [online] Retrieved on June 13, 2014 ,Available at : URL:http://www.ubst.dk/en/laws-and-

decrees/Ministerial\%20Order\%20concerning\%20the\%20Act\%20on\%20Uni versities\%20\%28The\%20University\%20Act\%29.pdf

El Amine, Adnan, editor (2014). Quality Issues in Higher Education in the Arab Countries, Beirut, Lebanese Association for Educational Studies (LAES) (. [online] Retrieved on June 13th, 2014 , Available at :

URL:http://www.laes.org/_publications.php?lang=en\&id=68)

Elsayad (2014). Reform of Higher Education Institutes in Egypt, Comparative \& International Higher Education, 6, 12-15.

El-Seoud, Samir Abou et al. (2013). Implementation of Web-Based Education in Egypt through Cloud Computing Technologies and Its Effect on Higher Education, Higher Education Studies, 3(3), 62-76.

Fahim (2009). Financing Higher Education in Egypt, Cairo: Economic Research Forum.

Fahim \& Sami (2010). Financing higher education in Egypt. In Financing higher education in Arab countries, ed. A. Galal \& T. Kanaan, 11-28. Cairo: Economic Research Forum.

Hazelkorn (2008). Learning to live with league tables and ranking: The experience of institutional leaders. Higher Education Policy, 21(2), 193-215. Hazelkorn (2011). Rankings and the Reshaping of Higher Education: The Battle for World-Class Excellence. London: Palgrave Macmillan.

Helal, Samir. Higher Education Reform in Egypt; A Bologna Process Based Cooperation Proposal, [online] Retrieved on June 13th, 2014 , Available at:

URL:http://barcelona2011.bolognaexperts.net/sites/default/files/i-

higher_education_reform_in_egypt-bologna_document.pdf

Kerr (2001). The Use of the University. Third Edition. Cambridge, MA: Harvard University Press.

ICTP (2008). ICTP progress report Q4, [online] Retrieved on July 15th, 2014. Available at: URL:http://www.ictp.org.eg

King, Marginson \& Naidoo, R. (Eds.) (2011). Handbook on Globalization and Higher Education. Cheltenham: Edward Elgar.

Levin, Jeong, Ou Dongshu (2006). "What is world-class university?" [online] Retrieved on June 13th, 2014 , Available at :

URL:http://www.tc.columbia.edu/centers/coce/pdf_files/c12.pdf

Li et al. (2008). The Higher Educational Transformation of China and its Global Implications. NBER Working, 13849, p. 5. Cambridge: National Bureau of Economic Research.

Lindsey (2012). Freedom and reform at Egypt's universities. The Carnegie Papers, Washington, DC. 
Ma (2008). The University of California at Berkeley: An emerging global research university. Higher Education Policy, 21, 65-81.

Marginson (2008). “Ideas of a University” for the global era. Paper for seminar on "Positioning university in the globalized world: Changing governance and coping strategies in Asia”. Centre of Asian Studies, the University of Hong Kong; Central Policy Unit, HKSAR Government; and the Hong Kong Institute of Education. 10-11 December 2008, The University of Hong Kong, [online] Retrieved on June 13th, 2014 . Available at :

URL:http://www.cshe.unimelb.edu.au/people/staff_pages/Marginson/Margin son. html.

Marginson (2011). Global perspectives and strategies of Asia-Pacific universities. In N. Liu, Q. Wang, \& Y. Cheng (Eds.), Paths to a World-class university: Lessons from Practices and Experiences (pp. 3-27). Rotterdam: Sense Publishers.

Ministry of Higher Education (MHE) (2013). Freshmen Student Guide for Admission at Higher Education Institutes. Cairo: MHE.

Noauthor (2005) "Reading Between the 'Red Lines': The Repression of Academic Freedom in Egyptian Universities,” 17 (6(E)). [online] Retrieved on June 13th, 2014 . Available at:

URL:http://www.hrw.org/reports/2005/egypt0605/egypt0 605.pdf.

OECD \& World Bank (2010). Higher education in Egypt. OECD and the World Bank.

Ramakrishna (2012). Building a world-class university system: Singapore's experience and practices. Journal of International Higher Education, 5(2), 81-82.

Rezk, Hanan \& Králiková, Katarína (2012). Ideas to Actions A pringeneration for EU-MENA Cooperation in Education, Belgium: center for European studies.

Rhee (2011). A World-Class Research University on the Periphery: The Pohang University of Science and Technology, the Republic of Korea. 68198.

Salmi, \& Liu (2011). Paths to a World-Class University. In Nian Cai, Wang , Qi and Cheng ,Ying (Eds.), Paths to a World-class university: Lessons from Practices and Experiences, The Netherlands: Sense Publishers.

Salmi (1992). The Higher Education Crisis in Developing Countries: Issues, Problems, Constraints and Reforms, International Review of Education 32 (1): 19-33.

Salmi (2009). The Challenge of Establishing World-Class Universities. Washington D.C: The World Bank.

Salmi (2010). Ten Common Errors when Building a New world-class university, World Bank. 
Salmi (2011). The Road to Academic Excellence: Lessons of Experience. In Altbach ,Philip G. and Salmi ,Jamil (Eds.), The Road to Academic Excellence The Making of World-Class Research Universities, Washington D.C: World Bank.

Salmi (2013). Daring to Soar: A Strategy for Developing World-Class Universities in Chile, Pensamiento Educativo. Revista de Investigación Educacional Latinoamericana, 50(1), 130-146, doi:10.7764/PEL.50.1.2013.10.

Salmi (2014). Higher education in Finland: Achievements, Challenges and Opportunities, [online] Retrieved on June 13th, 2014 , Available at:

URL:http://www.minedu.fi/export/sites/default/OPM/Tapahtumakalenteri/20 14/12/Kk_johdon_seminaari_liitteet/Jamil_Salmi_Report_Higher _Education_in_Finland.pdf

Schwab (2015). The Global Competitiveness Report: 2015-2016. Geneva, Switzerland: World Economic Forum.

Sekran (2001). Function of the Egyptian university in light of traditional and modern perspectives, Cairo: Home of Culture publisher and distributor.

Shann, Mary. (1992) .The Reform of Higher Education in Egyp,t 24 (2): 225246.

Sharma (2011). How to create a world-class university. Journal of World University New, 192: 59- 63.

The Russell Group of Universities (2012). Jewels in the crown: The importance and characteristics of the UK's world-class universities, Russell Group Papers - Issue 4.

Wilkens (2011). Higher Education Reform in the Arab World. In The Brookings project on U.S. relations with the Islamic world. 2011 U.S.Islamic World Forum Papers. Washington, DC: The Brookings Institution.

Williams \& Van Dyke (2007). "Measuring the International Standing of Universities with an Application to Australian Universities." Higher Education 53 (6): 819-841.

World Bank (2002). Constructing Knowledge Societies: New Challenges for Tertiary Education. Washington, DC: World Bank.

World Bank (2009).The Towers of Learning: Performance, Peril and Promise of Higher Education in Sri Lanka. Washington, DC: The World Bank- Human Development Unit, South Asia Region. 